\title{
Polymerase chain reaction for the diagnosis of viral hepatitis B and C
}

\author{
C Bréchot
}

\begin{abstract}
Polymerase chain reaction is a highly sensitive technique for the detection of hepatitis $B$ virus-DNA and hepatitis $C$ virus-RNA in serum, liver tissue, and peripheral mononuclear blood cells. In chronic hepatitis $B$, it is particularly useful for identification of infectious subjects who are hepatitis $B$ surface antigen positive and anti-hepatitis $B$ e antigen antibody-positive, and for follow up of hepatitis $B$ virus infections in liver transplantation programmes. Polymerase chain reaction detection of hepatitis $C$ virusRNA in serum may be the only means of confirming acute hepatitis $\mathrm{C}$ infection and also of identifying viraemia in the chronic disease, particularly in anti-hepatitis $C$ virus antibody-negative individuals. It can also be used for direct evaluation of mother to child hepatitis $C$ virus transmission. As in hepatitis $B$, polymerase chain reaction can be used for monitoring reinfection with hepatitis $\mathbf{C}$ virus after liver transplant, and has proved invaluable in identification of different hepatitis $C$ virus genotypes. The efficacy of antiviral treatment can also be monitored using polymerase chain reaction. Polymerase chain reaction has thus shown numerous advantages for disease detection and monitoring despite the limitations imposed, for example, by possible contamination problems and semiquantitative evaluations. (Gut 1993; supplement: S39-S44)
\end{abstract}

Polymerase chain reaction (PCR) is certain to modify the approach to the diagnosis of viral hepatitis. While it provides a direct and highly sensitive identification of viral genomes, however, it has three important limitations: (a) the risk of false positive results because of contamination; (b) difficulties in developing quantitative tests; (c) the need for automisation and use of non-radioactive probes for wider availability of the technique. This review will discuss different clinical and practical uses of PCR for the diagnosis of viral hepatitis, focusing on the hepatitis $B$ and $C$ viruses.

Hybridotest

Laboratory,

Pasteur Institute,

Liver Unit,

Laennec Hospital,

Paris, France

C Bréchot

Correspondence to:

Dr C Bréchot,

Hybridotest Laboratory,

Pasteur Institute,

Liver Unit,

Laennec Hospital,

Paris, France.
HEPATITIS B VIRUS (HBV)

Conventional hybridisation procedures have now been used widely for the detection of HBV-DNA in serum, tissues, and mono- nuclear blood cells. ${ }^{12} \mathrm{HBV}-\mathrm{DNA}$ is the most direct and sensitive test for viral multiplication and semiquantitative tests have been developed, based on liquid hybridisation. ${ }^{34}$ The limit of sensitivity, however, is $10^{5}-10^{6}$ particles $/ \mathrm{ml}$ of serum or plasma.

There is a need for more sensitive tests to identify the HBV-DNA sequences, based on the following: (a) hepatitis B surface antigen (HBsAg) positive blood donors or mothers have been shown to transmit $\mathrm{HBV}$ infection despite being positive for antibodies to hepatitis $\mathrm{B}$ e antigen (anti-HBe) and HBVDNA negative in serum ${ }^{5}$; (b) some patients with $\mathrm{HBsAg}$ positive/anti-HBe positive chronic active hepatitis have active liver disease despite serum HBV-DNA negativity and absence of hepatitis delta virus or hepatitis $\mathrm{C}$ virus (HCV) coinfections, autoimmune liver disease, or other causes of liver disease; (c) it is important to have a precise follow up of patients under antiviral treatment, to evaluate partial or complete responses and the subsequent risk of reactivation; (d) PCR is necessary for subsequent sequencing of the amplified products (either direct sequencing or sequencing after cloning). ${ }^{2}$ It has provided information on the genetic variability of $\mathrm{HBV}$ and the potential implication of mutations in the pre-C, C, and pre-S/S viral sequences in the persistence of HBV infection, severity of liver disease, and response to treatment ${ }^{7-12}$; (e) HBsAg negative patients with acute and chronic liver diseases have been shown to contain HBV-DNA sequences in the blood, liver, or mononuclear cells. HBV-DNA has also been shown in blood donors with no HBV serological marker. ${ }^{2} 813-26$ The reliable detection and characterisation of these sequences is facilitated by PCR.

\section{$H B s A g$-positive patients}

Several studies have highlighted the potential use of PCR for HBV-DNA detection. ${ }^{27-40}$ Representative results obtained in our laboratory are shown in the Figure, ${ }^{30}$ showing serum HBV-DNA in $50 \%$ of HBsAg positive/ anti-HBe positive asymptomatic carriers who were $\mathrm{HBV}-\mathrm{DNA}$ negative in a regular spot test. In contrast, HBV-DNA was shown in almost all $\mathrm{HBsAg}$ positive subjects with chronic active hepatitis, but not in cases of resolved acute hepatitis or negative controls.

Two main conclusions can be drawn from these findings: firstly, PCR is a highly sensitive test, detecting as few as $10 \mathrm{HBV}$ particles $/ \mathrm{ml}$; secondly, the PCR test is not positive for all HBV carriers and thus may have prognostic implications. 


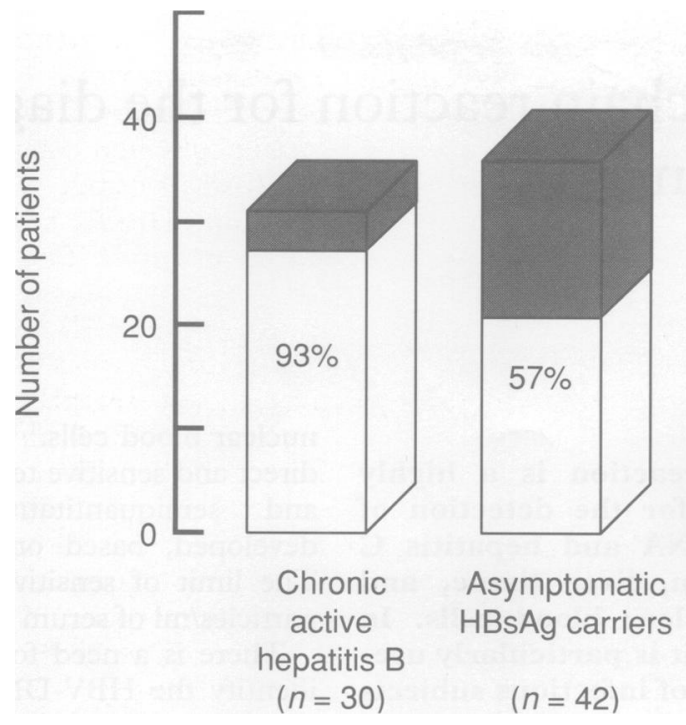

Figure $\quad P C R$ assay of HBV-DNA in chronic HBV carriers.

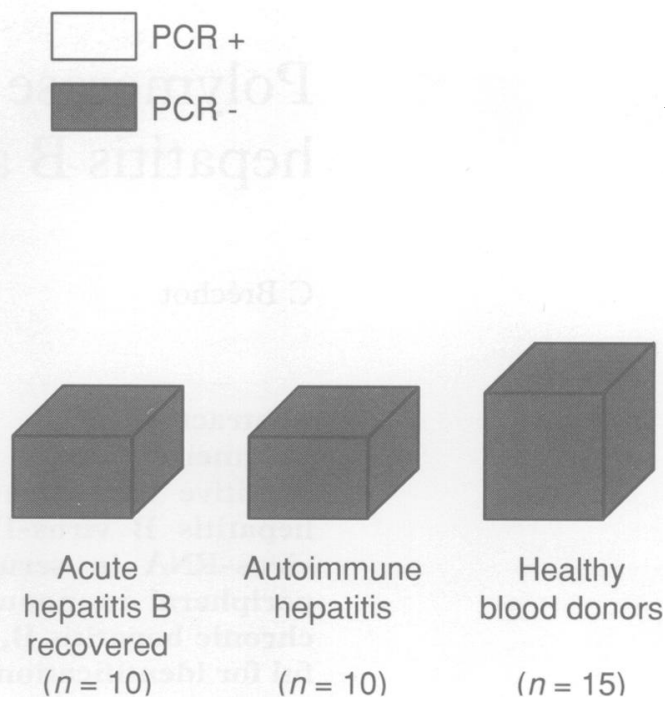

detection has improved considerably the sensitivity and specificity of serological tests. There are still several limitations, however, including delayed seroconversion in acute infection (about six to eight weeks on average), apparent $\mathrm{HCV}$ infection in seronegative individuals, difficulties in interpreting some 'indeterminate' results, and the absence of a test for detecting HCV antigens and, thus, of serological tests for HCV multiplication.

\section{Detection of $H C V-R N A$}

PCR can be used for the detection of HCVRNA in serum, liver, and mononuclear cells. The efficiency of detection is dependent upon conservation of samples, the amount of material available (100 to 200 microlitres are sufficient), and the specific primers used. Primers located on the $5^{\prime}$ non-coding part of $\mathrm{HCV}$ are the most efficient; negative results may be confirmed by using primers on other parts of HCV genome (capsid, NS5, for example). There is also the question of nested $v$ single step PCR. Nested PCR is highly sensitive but also highly susceptible to contamination. To minimise these problems, we use either nested PCR with the two steps performed in a single tube, ${ }^{43}$ or single step PCR with three primers (one for cDNA and two different primers for the PCR).

The use of PCR for the detection of HBVDNA is still limited in routine clinical use to three areas: detection of $\mathrm{HBV}$ multiplication in $\mathrm{HBsAg}$ positive/anti-HBe positive patients with active liver disease despite a negative spot test for HBV-DNA; appraisal of HBsAg negative liver diseases; follow up of $\mathrm{HBV}$ infections in liver transplantation programmes. Future potential uses will include follow up of antiviral treatment (dependent on quantification) and detection of HBV-DNA in blood donors (dependent on automisation).

HEPATITIS C VIRUS (HCV)

The recent development of 'second and third generation' tests for anti-HCV antibody

\section{Determination of HCV viraemia}

PCR allows for a direct determination of $\mathrm{HCV}$ viraemia one week after contamination. ${ }^{44} 45$ Furthermore, it is now clear that most antiHCV positive patients with chronic hepatitis have HCV-RNA detectable in the serum (Table I). A few anti-HCV positive individuals are HCV-RNA negative, however, and it is not yet clear whether they have intermittent viraemia. ${ }^{43}$ 46-54 In contrast, recent evidence from our laboratory indicates that only a subset of blood donors with repeatedly normal activities of alanine aminotransferase has viraemia; in acute infection it can identify HCV 
TABLE I Anti-HCV and HCV-RNA in chronic NANB hepatitis (From: Porchon et al. $\mathcal{F}$ Hepatol) ${ }^{50}$

\begin{tabular}{|c|c|c|c|}
\hline \multirow[t]{2}{*}{ Patients } & \multicolumn{2}{|c|}{ Anti-HCV } & \multirow[t]{2}{*}{$H C V-R N A($ serum $)$} \\
\hline & $E L I S A-1$ & $R I B A-2$ & \\
\hline 18 & + & + & + \\
\hline 4 & - & + & + \\
\hline 5 & - & - & + \\
\hline 4 & + & + & - \\
\hline 1 & - & + & - \\
\hline 4 & - & - & - \\
\hline 36 & \multicolumn{2}{|c|}{$27 / 36$} & $27 / 36$ \\
\hline
\end{tabular}

detectable serum HCV-RNA; this suggests that PCR might allow the identification of individuals for further investigation and, possibly, treatment. It has also been found that anti-HCV negative subjects can be HCV-RNA positive. This has been shown both in patients with chronic hepatitis and in blood donors implicated in post-transfusional hepatitis. ${ }^{53} 54$ As for hepatitis B, HCV-RNA detection might be used in the future for the follow up of hepatitis $\mathrm{C}$ patients receiving treatment with interferon. Semiquantitative evaluation of HCV-RNA has been performed but is not really applicable at present. This will be a major challenge in the next few years.

\section{Evaluation of the role of $\mathrm{HBV}$ or $\mathrm{HCV}$ in some liver diseases: the value of negative PCR tests}

A negative result with PCR is of significance because of the extreme sensitivity of the test.

HCV AND FULMINANT HEPATITIS

We have evaluated the potential role of PCR in fulminant hepatitis (Table II). ${ }^{43}$ In this study, HCV-RNA was not detected in any patients with fulminant hepatitis of unknown cause. In contrast, HCV-RNA was detected in a significant proportion of patients with $\mathrm{HBsAg}$ positive fulminant hepatitis, suggesting coinfection or superinfection by $\mathrm{HCV}$ as a potential risk factor.

TABLE II PCR results in patients with $H B s A g$ positive or indeterminate fulminant hepatitis (From: Féray C, et al. f Clin Invest 1992; 89: 1361-5)

\begin{tabular}{|c|c|c|c|c|c|c|}
\hline & \multirow[t]{2}{*}{ Anti-HCV } & \multirow[t]{2}{*}{ Anti-HEV } & \multicolumn{2}{|c|}{$H C V-R N A$} & \multicolumn{2}{|c|}{$H B V-D N A$} \\
\hline & & & Serum & Liver & Serum & Liver \\
\hline $\begin{array}{l}\text { Group } 1(n=17) \\
\text { (HBsAg positive) }\end{array}$ & 0 & 0 & 7 & $4 / 6$ & 10 & $8 / 8$ \\
\hline $\begin{array}{l}\text { Group } 2(n=23) \\
\quad \text { (Indeterminate) }\end{array}$ & 0 & 0 & 0 & $0 / 5$ & 1 & $0 / 6$ \\
\hline
\end{tabular}

TABLE III Nucleotide sequence homology in the $E_{2} / N S_{1}$ hypervariable domain (From: Féray, et al. f Clin Invest 1992; 89: 1361-5)

\begin{tabular}{|c|c|c|c|c|}
\hline & \multirow{2}{*}{ 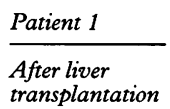 } & \multirow{2}{*}{ 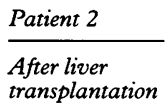 } & \multirow[t]{2}{*}{$H C V-P t$} & \multirow[t]{2}{*}{$H C V-7$} \\
\hline & & & & \\
\hline $\begin{array}{l}\text { Patient } 1 \\
\quad \text { Before liver transplantation }\end{array}$ & $95 \%$ & $70 \%$ & $78 \%$ & $63 \%$ \\
\hline $\begin{array}{l}\text { Patient } 2 \\
\text { Before liver transplantation }\end{array}$ & $69 \%$ & $96 \%$ & $64 \%$ & $55 \%$ \\
\hline
\end{tabular}

HBV AND HCV REINFECTION AFTER LIVER TRANSPLANTATION

Immunotherapy with anti-HBs specific immunoglobulin can prevent $\mathrm{HBV}$ reinfection in $\mathrm{HBsAg}$ positive patients who were $\mathrm{HBV}$ DNA and HBeAg negative at the time of liver transplantation. Testing by PCR for HBVDNA in mononuclear cells and liver samples in this group of HBsAg negative subjects after transplantation has shown negative results in liver biopsy samples but positive results in peripheral blood mononuclear cells. This indicates that PCR can be useful for the evaluation of $\mathrm{HBV}$ infection in liver transplantation. Also, the presence of HBVDNA in peripheral blood mononuclear cells probably accounts for the reappearance of HBV infection in the liver graft in up to $30 \%$ of these subjects. ${ }^{56}$ We have recently validated PCR as the most reliable test to identify $\mathrm{HCV}$ infection after liver transplantation. It has also been possible to show direct recurrence of $\mathrm{HCV}$ infection in the liver graft by the original HCV strain ${ }^{43}$ (Table III).

\section{PCR for the detection of HCV-RNA and HBV-DNA in tissues and peripheral blood mononuclear cells}

FROZEN TISSUES

PCR can be used to detect HBV-DNA, HBVRNA, and HCV-RNA in frozen liver biopsy specimens. PCR has also been used for HBVDNA detection in paraffin embedded liver sections ${ }^{57-61}$ despite a reduction in sensitivity of around tenfold in our experience. HCV-RNA has yet to be detected in paraffin embedded liver samples. It has been possible to confirm the presence of HBV-DNA and HBV-RNA in liver samples of patients with $\mathrm{HBsAg}$ negative chronic liver diseases, including hepatocellular carcinoma. ${ }^{57}$ The HBV-DNA sequences identified in tissue tumours can be transcriptionally active as HBV-RNA has also been identified. More recently, HCV-RNA positive and negative strands have been shown in these tumours indicating ongoing viral multiplication in the tumour cells. Finally, HCVRNA can be identified in some liver biopsy specimens despite a negative serum test.

PERIPHERAL BLOOD MONONUCLEAR CELLS (PBMNC)

HBV-DNA has been identified in PBMNC using classic hybridisation procedures. ${ }^{62}$ PCR has recently proved the presence of HBV-RNA in these cells. ${ }^{63}$ HCV-RNA positive and negative strands can also be shown in PBMNC, indicating that, as for flavi and pestiviruses, $\mathrm{HCV}$ infects mononuclear cells. ${ }^{64}$

There are limitations associated with the interpretation of PCR tests for the detection of viral genes in tissues or PBMNC. For example, how can contamination from serum or nontumorous liver cells (in studies on hepatocellular carcinoma) or from serum particles absorbed on PBMNC (in studies on mononuclear cells) be ruled out, given that 
PCR is such a sensitive procedure? We have adopted a number of different techniques. For HBV-DNA and hepatocellular carcinoma we have used different primers and shown different patterns of positivity in serum and non-tumorous cells as compared with the tumour - that is, presence of defective viral genomes only in the tumour. ${ }^{61}$ For HCV-RNA in PBMNC, we have shown that mitogens (such as PHA/PMA) will enhance $\mathrm{HCV}$ multiplication in short term $(24-76 \mathrm{~h})$ cultures of PBMNC. ${ }^{64}$

It is also possible to take advantage of the viral genetic variability. For example, sequences of the E2/NS1 hypervariable region show significant mutations in the same strain when comparing HCV-RNA extracted from tumorous and non-tumorous liver tissue from patients with hepatocellular carcinoma. This means that the positivity of HCV-RNA in the tumour is not due to minute contamination from non-tumorous cells. It also underlines a different rate of replication and mutation in tumorous and non-tumorous liver cells. ${ }^{61} 6566$

\section{PCR for the analysis of $\mathrm{HBV}$ and $\mathrm{HCV}$ genetic variability: clinical implications}

$\mathrm{HCV}$

The comparison of nucleotide sequences from the published HCV genomes in Japan, USA, and Europe highlights the existence of distinct subtypes of $\mathrm{HCV}$. The 5 ' non-coding and, to a lesser extent, the core and NS3-NS4 regions of the viral genome are well conserved among different isolates. In contrast, the open reading frames encoding the E1 and E2/NS1 envelope proteins are much less conserved. In the ${ }^{\prime}$ part of the E2/NS1 sequence is located a 'hypervariable' domain (Table III).$^{65} 66$

It is possible to take advantage of this 'hypervariable' domain to identify precisely an HCV strain as well as its mutations during follow up. This will be achieved by amplification of the 'hypervariable' domain using primers located on both sides of the E2/NS1 sequence, followed by nucleotide sequence analysis of the hypervariable domain.

\section{Mother to child HBV and HCV transmission}

HBV

Mother to child HBV transmission can be identified by serological tests. PCR may only be of interest in clinical investigations on the transmission of some HBV mutants.

HCV

HCV-RNA is currently the only direct marker used to investigate mother to child $\mathrm{HCV}$ transmission. Several studies have indicated that, in most cases, anti-HCV from the mother infected with the virus will persist in newborns until about 12 months after birth. In some rare instances, HCV-RNA has been detected repeatedly in the neonates, indicating $\mathrm{HCV}$ transmission. This seems to be a rare event, except for mothers infected by both $\mathrm{HCV}$ and HIV (when the level of $\mathrm{HCV}$ viraemia is usually higher).$^{67-72}$ Prospective studies are now required to evaluate the long term consequence of these infections.

\section{Conclusions}

Despite the numerous advantages listed in this review, there are still limitations to the routine use of PCR, both in the procedure itself as well as in the interpretation of the results. The Tables IV and V summarise main applications, advantages, and limitations of PCR.

\section{MAIN CLINICAL INDICATIONS FOR PCR IN HBV AND HCV DIAGNOSIS}

\section{$H B V$}

PCR can be used for the identification of low level HBV viraemia in $\mathrm{HBsAg}$ positive subjects with active liver disease without HBV-DNA positivity in standard hybridisation techniques or evidence of other causes of liver disease. It is also useful for the appraisal of HBV infection in liver transplantation, evaluation of antiviral treatment (although the question of quantification remains), and for the diagnosis of $\mathrm{HBsAg}$ negative acute or chronic liver disease. The implications of genetic variability of HBV have yet to be determined.

\section{$H C V$}

PCR can be used for the diagnosis of acute $\mathrm{HCV}$ infection and the anti-HCV negative patient with chronic hepatitis, evaluation of $\mathrm{HCV}$ viraemia in asymptomatic blood donors with normal alanine aminotransferase activity,

\section{TABLE IV Advantages associated with the use of PCR in viral hepatitis \\ Sensitive estimation of viral multiplication (too sensitive?) =HBV, $\mathrm{HCV}, \mathrm{HDV}$ \\ - evaluation of degree of infection? \\ - follow up of antiviral treatment \\ $\rightarrow$ Quantification? \\ Detection of HBV-DNA and HCV-RNA in seronegative patients - delayed seroconversion in acute HCV infection \\ - seronegative chronic carriers (HBV and HCV) \\ Direct evaluation of mother to child HCV transmission \\ Analysis of genetic variability and its implications ( $\mathrm{HBV}, \mathrm{HCV}$ )}

TABLE V Limitations of the PCR assay

\begin{tabular}{l}
\hline Technical \\
- False positives (contamination) and false negatives \\
(quality of DNA and RNA) \\
- PCR with HLA (DNA) or cyclin (RNA) primers \\
- Amount of serum or plasma used. Conservation. \\
- Design of primers (prediction of sequence analysis?) \\
- Single step (three primers) or nested PCR (one tube assay)? \\
- Quantification? \\
\hline 2 Interpretation \\
- Intact or defective genomes? \\
- 'Capture' with anti-HBs (HCV?) before PCR? \\
- Comparison with infectious doses \\
- Contamination of PBMNC or tissue samples by serum \\
- In situ hybridisation \\
- PCR profile with different primers \\
- Sequence comparison
\end{tabular}


diagnosis of anti-HCV positive chronic hepatitis with anti-LKM1 autoantibodies, and the decision of whether or not to treat these patients with interferon. It is also useful in the evaluation of $\mathrm{HCV}$ infections after liver transplantation, investigation of mother to child HCV transmission, and follow up of the effects of antiviral treatment (although quantification is still questionable).

1 Scotto J, Hadchouel M, Hery C, Yvart J, Tiollais P, Bréchot C. Detection of hepatitis B virus DNA in serum by a simple spot hybridization technique: comparison with results for other viral markers. Hepatology 1983; 3: with result $279-84$.

2 Bréchot C. Polymerase chain reaction. A new tool for the study of viral infections in hepatology. F Hepatol 1990; 11: 124-9.

3 Kuhns MC, McNamara AL, Cabal CM, et al. A new assay for the quantitative detection of hepatitis B viral DNA in human serum. In: Zuckerman AJ, ed. Viral hepatitis and liver disease. New York: Alan R Liss, 1988: 258-62.

4 Zarski JP, Kuhns M, Berck L, et al. Comparison of a quantitative standardized HBV-DNA assay and a classical spot hybridization test in chronic active hepatitis B patients undergoing antiviral therapy. Res Virol 1989; 140: patients

5 Krogsgaard K, Wantzin P, Aldershvile J, Kryger $P$, Andersson P, Nielson JO. Hepatitis B virus DNA in hepatitis $B$ surface antigen-positive blood donors: Relation to the hepatitis $\mathrm{B}$ e system and outcome in recipients. F Infect Dis 1986; 153: 298-303.

6 Lee SD, Lo KJ, Wu JC, et al. Prevention of maternal-infant hepatitis $B$ virus transmission by immunization: the role of serum hepatitis B virus DNA. Hepatology 1986; 6: 369-73.

7 Carman WF, Hadziyannis S, McGarvey MJ, et al. Mutation preventing formation of hepatitis $\mathrm{B}$ e antigen in patients with chronic hepatitis B infection. Lancet 1989; ii: 588-90.

8 Carman WF, Zanetti AR, Karayiannis $\mathrm{P}$, et al. Vaccineinduced escape mutant of hepatitis B virus. Lancet 1990; 336: 325-9.

9 Brunetto MR, Stemler M, Bonino F, et al. A new hepatitis $B$ virus strain in patients with severe anti-HBe positive chronic hepatitis B. $\mathcal{F}$ Hepatol 1990; 10: 258-61.

10 Brown WL, William F, Carman F, Thomas SC. The clinical significance of molecular variation within the hepatitis B virus genome. Hepatology 1992; 15: 144-8.

11 Gerken G, Kremsdorf D, Capel F, et al. Hepatitis B defective virus with rearrangements in the PreS gene during chronic HBV infection. Virology 1991; 183: 555-65.

12 Tran A, Kremsdorf D, Capel F, et al. Emergence of and takeover by hepatitis B virus (HBV) with rearrangements in the Pre-S/S and Pre-C/C genes during chronic HBV infection. F Virol 1991; 65: 3566-74

13 Coursaget P, Le Cann P, Leboulleux D, Diop MT, Bao O, Coll AM. Detection of hepatitis B virus DNA by polymerase chain reaction in $\mathrm{HBsAg}$ negative Senegalese patients suffering from cirrhosis or primary liver cancer. FEMS Lett 1991; 35-8.

14 Kaneko S, Miller RH, Feinstone SM, et al. Detection of serum hepatitis B virus DNA in patients with chronic hepatitis using the polymerase chain reaction assay. Proc Natl Acad Sci USA 1989; 86: 312-6.

15 Kremsdorf D, Thiers V, Garreau F, et al. Variabilité génétique du virus de l'hépatite $\mathbf{B}$ et son expression sérologique. Médecine-Sciences 1990; 6: 108-16.

16 Lai ME, Farci P, Figus A, Balestrieri A, Arnone M, Vygas GN. Hepatitis B virus DNA in the serum of Sardinian blood donors negative for the hepatitis B Sardinian blood donors negative for

17 Liang TJ, Blum HE, Wands JR. Characterization and biological properties of a hepatitis B virus isolated from a patient without hepatitis $B$ virus serologic markers. Hepatology 1990; 12: 204-12.

18 Liang TJ, Baruch Y, Ben-Porath E, et al. Hepatitis B virus infection in patients with idiopathic liver disease. Hepatology 1991; 13: 1044-51.

19 Lugassy C, Bernuau J, Thiers V, et al. Sequences of hepatitis $B$ virus DNA in the serum and liver of patients with acute benign and fulminant hepatitis. $\mathcal{F}$ Infect Dis 1987; 155: 64-71.

20 Paterlini P, Gerken G, Nakajima E, et al. Polymerase chain reaction to detect hepatitis $B$ virus DNA and RNA sequences in primary liver cancers from patients negative for hepatitis B surface antigen. $N$ Engl f Med 1990; 323: $80-5$.

21 Pontisso P, Morsica G, Ruvoletto MG, et al. Latent hepatitis $B$ virus infection in childhood hepatocellular carcinoma, analysis by polymerase chain reaction. Cancer (in press).

22 Rumi MG, Colombo M, Romeo R, Colucci G, Gringeri A Manucci PM. Serum hepatitis B virus DNA detects cryptic hepatitis B virus infections in multitransfused hemophilic patients. Blood 1990; 75: 1654-8.

23 Thiers V, Fujita Y, Takahashi H, et al. Hepatitis B virus DNA sequences in the serum of HBsAg-negative patients with chronic liver disease. In: Zuckerman $\mathrm{AJ}$, ed. Viral hepatitis and liver disease. New York: Alan R Liss, 1988: 553-7.

24 Thiers V, Nakajima E, Kremsdorf D, et al. Transmission of hepatitis B from hepatitis B seronegative subjects. Lancet 1988; ii: $1273-6$.

25 Thiers V, Lunel-Fabiani F, Valla D, et al. Post-transfusional anti-HCV negative Non-A Non-B hepatitis (II): serological and polymerase chain reaction analysis for hepatitis $C$ and hepatitis B viruses. $\mathcal{F}$ Hepatol (in press).

26 Wang JT, Wang TH, Sheu JC, Shih LN, Lin JT, Chen DS Detection of hepatitis $B$ virus DNA by polymerase chain reaction in plasma of volunteer blood donors negative for hepatitis B surface antigen. F Infect Dis 1991; 163: 397-9.

27 Barlet V, Zarski JP, Thelu MA, Seigneurin JM. Advantage of PCR for detecting low amounts of HBV DNA in patients' sera. Res Virol 1991; 142: 373-9.

28 Baker BL, Di Bisceglie M, Kaneko S, et al. Determination of hepatitis B virus DNA in serum using the polymerase chain reaction: Clinical significance and correlation with serological and biochemical markers. Hepatology 1991; serological

29 Chemin I, Baginski I, Petit MA, et al. Correlation between HBV DNA detection by polymerase chain reaction and Pre $\mathrm{S} 1$ antigenemia in symptomatic and asymptomatic hepatitis B virus infections. $\mathcal{f}$ Med Virol 1991; 33: 51-7.

30 Gerken G, Paterlini P, Manns M, et al. Assay of hepatitis $B$ virus DNA by polymerase chain reaction and its relationship to Pre $S$ and $S$ encoded viral surface antigens. Hepatology 1991; 13: 158-61.

31 Kaneko S, Feinstone SM, Miller RH. Rapid and sensitive method for the detection of serum hepatitis B virus DNA using the polymerase chain reaction technique. $\mathcal{F}$ Clin Microbiol 1989; 27: 1930-3.

32 Larzul D, Guigue F, Sninsky JJ, Mack DH, Bréchot C, Guesdon JL. Detection of hepatitis B virus sequences in serum by using in vitro enzymatic amplification. $\mathcal{F}$ Virol Methods 1988; 20: 227-37.

33 Larzul D, Chevrier D, Thiers V, Guesdon JL. An automatic modified polymerase chain reaction procedure for hepatitis B virus DNA detection. F Virol Methods 1990; 27: 49-60.

34 Liang JT, Isselbacher KJ, Wands JR. Rapid identification of low level hepatitis B-related viral genome in serum. $f$ Clin Invest 1989; 84: 1367-71.

35 Ljunggren K, Kidd AH. Enzymatic amplification and sequence analysis of precore/core DNA in HBsAg positive patients. $\mathcal{F}$ Med Virol 1991; 34: 179-83.

36 Loriot MA, Marcellin P, Bismuth E, et al. Demonstration of hepatitis B virus DNA by polymerase chain reaction in the serum and the liver after spontaneous or therapeutically induced $\mathrm{HBeAg}$ to anti-HBe or $\mathrm{HBsAg}$ to anti-HBs seroconversion in patients with chronic hepatitis B. Hepatology 1992; 15: 32-6.

37 Marcellin P, Martinot-Peignoux M, Loriot MA, et al. Persistence of hepatitis B virus DNA demonstrated by polymerase chain reaction in serum and liver after loss of HBsAg induced by antiviral therapy. Ann Intern Med 1990; 112: 3 .

38 Quint WGV, De Bruijin I, Kruining H, Heijtink RA. HBVDNA detection by gene amplification in acute hepatitis B. Hepatology 1990; 12: 653-6.

39 Ulrich PP, Bhat RA, Seto B, Mack D, Sninsky J, Vyas GN. Enzymatic amplification of hepatitis B virus DNA in serum compared with infectivity testing chimpanzees. f Infect Dis 1989; 160: 37-43.

40 Yokosuka $O$, Omata $M$, Hosoda $K$, Tada $M$, Ehata $T$, Ohto $M$. Detection and direct sequencing of hepatitis $B$ virus genome by DNA amplification method. Gastroenterology 1991; 100: 175-81.

41 Liang TJ, Blum HE, Wands JR. Characterization and biological properties of a hepatitis B virus isolated from a patient without hepatitis $B$ virus serologic markers. Hepatology 1990; 12: 204-12.

42 Kremsdorf D, Thiers V, Garreau F, et al Nucleotide sequence analysis of three hepatitis B virus genomes isolated from serologically negative patients. In: Hollinger FB, Lemon SM, Margolis HS, eds. Viral hepatitis and liver FB, Lemon SM, Margolis HS, eds. Viral hepatitis and liver

43 Féray C, Samuel D, Thiers V, et al. Reinfection of liver graft by hepatitis $\mathrm{C}$ virus (HCV) after liver transplantation. f Clin Invest 1992; 89: 1361-5.

44 Shimizu YK, Weiner AJ, Rosenblatt J, et al. Early events in hepatitis C virus infection of chimpanzees. Proc Natl Acad Sci 1990; 87: 6441-4.

45 Farci $\mathrm{P}$, Alter HJ, Wong $\mathrm{D}$, et al. A long-term study of hepatitis $\mathrm{C}$ virus replication in non-A, non-B hepatitis. $N$ Engl f Med 1991; 325: 98-104.

46 Kato N, Yokosuka O, Omata M, Hosoda $\mathrm{K}$, Ohto $M$ Detection of hepatitis $\mathrm{C}$ virus ribonucleic acid in the serum by amplification with polymerase chain reaction. serum by amplification with poly

47 Garson JA, Tuke PW, Makris $M$, et al. Demonstration of viraemia patterns in haemophiliacs treated with hepatitis C virus contaminated factor VIII concentrates. Lancet 1990; 336: 1022-5.

48 Hagiwara H, Hayashi N, Mita E, et al. Detection of hepatitis $C$ virus RNA in chronic non-A non-B liver disease. Gastroenterology (in press).

49 Kato N, Hijikata M, Oostsuyama Y, et al. Molecular cloning of the human hepatitis $C$ genome from Japanese patients with non-A, non-B hepatitis. Proc Natl Acad Sci USA 1990; 87: 9524-8.

50 Porchon C, Kremsdorf D, Pol S, et al. Serum hepatitis virus RNA and hepatitis $B$ virus DNA in non-A, 
non-B post-transfusional and sporadic chronic hepatitis. $f$ Hepatol (in press).

51 Takekara T, Hayashi N, Mita E, et al. Detection of minus strand of hepatitis C virus RNA by reverse transcription and polymerase chain reaction. Implication for hepatitis $\mathrm{C}$ and polymerase chain reaction. Implication for hepatitis
virus replication in infected tissue. Hepatology (in press)

52 Ulrich PP, Romeo JM, Lane PK, Kelly I, Daniel LJ, Vyas GN. Detection, semiquantification and genetic variation in hepatitis $C$ virus sequences amplified from the plasma of blood donors with elevated alanine aminotransferase. $\mathcal{F}$ Clin Invest 1990; 86: 1609-14.

53 Weiner AJ, Kuo G, Bradley DW, et al. Detection of hepatitis C viral sequences in non-A, non-B hepatitis. Lancet 1990; 335: $1-3$.

54 Villa E, Feretti I, De Palma M, et al. HCV RNA in serum of asymptomatic blood donors involved in posttransfusion hepatitis (PTH). ₹ Hepatol 1991; 13: 256-9.

55 Féray C, Gigou M, Samuel D, et al. Hepatitis C virus RNA and hepatitis B virus DNA in serum and liver of patients with fulminant hepatitis.

56 Féray C, Zignego AL, Samuel D, et al. Persistent hepatitis B virus liver infection: the liver transplantation model. Transplantation 1990; 49: 1155-8.

57 Paterlini P, Gerken G, Nakajima E, et al. Polymerase chain reaction to detect hepatitis B virus DNA and RNA sequences in primary liver cancers from patients negative for hepatitis B surface antigen. N Engl f Med 1990; 323 : $80-5$.

58 Lampertico P, Malter JS, Colombo M, Gerber MA. Detection of hepatitis $B$ virus DNA in formalin-fixed, paraffin-embedded liver tissue by the polymerase chain paraftion. Am ₹ Pathol 1990; 240: 253-8.

59 Lo YMD, Mehal WZ, Fleming KA. In vitro amplification of hepatitis $B$ virus sequences from liver tumor DNA and from paraffin wax embedded tissues using the polymerase chain reaction. $f$ Clin Pathol 1989; 42: 840-6.

60 Shindo M, Okuno T, Arai K, et al. Detection of hepatitis $B$ virus DNA in paraffin-embedded liver tissues in chronic hepatitis B or non-A, non-B hepatitis using the polymerase chain reaction. Hepatology 1991 ; 13: 167-71.
61 Paterlini P, Franco D. Driss F, et al. Primary liver cancer in hepatitis B surface antigen-negative patients is associated with the persistence of hepatitis $B$ and hepatitis $C$ viral genomes in serum and tumorous tissue.

62 Pontisso P, Poon MC, Tiollais P, Bréchot C. Detection of hepatitis B virus DNA in mononuclear blood cells. $B M F$ 1984; 288: 1563-6.

63 Baginski I, Chemin I, Bouffard P, Hanzt H, Trépo C. Detection of polyadenylated RNA in hepatitis $B$ virus infected peripheral blood mononuclear cells by polymerase chain reaction. F Infect Dis 1991; 163: 996-1000.

64 Zignego AL, Macchia D, Monti M, et al. Infection of peripheral mononuclear blood cells by hepatitis $\mathrm{C}$ virus. $\mathcal{f}$ Hepatol (in press).

65 Houghton $M$, Weiner A, Han J, Kuo G, Choo QL Molecular biology of the hepatitis $\mathrm{C}$ viruses: Implications for diagnosis, development and control of viral disease. Hepatology 1991; 2: 381-8.

66 Kremsdorf D, Porchon C, Kim JP, Reyes GR, Bréchot C. Partial nucleotide sequence analysis of a French hepatitis $C$ virus: implications for HCV genetic variability in the E2/NS1 protein. $\mathcal{F}$ Gen Virol 1991; 72: 2557-61.

67 Inoue $\mathrm{Y}$, Miyamura T, Unayama T, Takahashi K, Saito I Maternal transfer of HCV. Nature 1991; 353: 609.

68 Degos F, Thiers V, Erlinger S, et al. Neonatal transmission of HCV from mother with chronic hepatitis. Lancet 1991; 338: 758 .

69 Kuroki T, Nishiguchi S, Fukuda K, et al. Mother-to-child transmission of hepatitis C virus. F Infect Dis 1991; 164: 427-8.

70 Novati R, Thiers V, D'Arminio Monforte A, et al. Motherto-child transmission of hepatitis $C$ virus detected by nested polymerase chain reaction. $\mathcal{F}$ Infect $D$ is (in press).

71 Roudot-Thoraval F, Pawlotsky JM, Thiers V, et al. Lack of mother-to-infant transmission of hepatitis $C$ virus. Prospective study using HCV-RNA testing. Submitted.

72 Thaler MM, Park CK, Landers DV, et al. Vertica transmission of hepatitis C virus. Lancet 1991; 338: 17-8. 